\title{
Currency Depreciation, Trade Balance and Intra-Industry Trade Interactions in Turkey's OECD Trade
}

\author{
Mehmet Demiral ${ }^{1,2}$ \\ ${ }^{1}$ Department of Economics, Nigde University, Nigde, Turkey \\ ${ }^{2}$ Visiting Scholar, Department of Economics, University of Southern California, Los Angeles, California, USA \\ Correspondence: Mehmet Demiral, Department of Economics, University of Southern California (USC), 3620 \\ South Vermont Ave., Kaprielian (KAP) Hall, 300, Los Angeles, California-90089, USA. Tel: 1-213-330-5353. \\ E-mail: mdemiral@nigde.edu.tr
}

Received: January 15, 2016

Accepted: February 13, 2016

Online Published: March 25, 2016

doi:10.5539/ijef.v8n4p8

URL: http://dx.doi.org/10.5539/ijef.v8n4p8

\begin{abstract}
This study re-examines the determinants of Turkey's trade balance in its manufactures trade with 33 OECD-member countries for the short-run and the long-run. Unlike other studies, in the relationships we also control the moderating effects of the availability of import substitutes proxied by intra-industry trade. We analyze quarterly aggregated time-series data of the period spanning from 1998.QI to 2015.QIII, following the autoregressive distributed lag (ARDL) bounds testing approach to the cointegration and the error correction modeling. Estimation results reveal that real effective exchange rate, together with domestic and foreign incomes are still among the core determinants of Turkey's trade balance in the manufacturing sectors. There is no significant impact of domestic final oil prices that also include all the taxes on gasoline. The trade balance depends on domestic income negatively and the aggregated income of the OECD countries positively. The finding that real depreciation of Turkish lira against to those of Turkey's OECD trade partners improves trade balance in both the short-run and the long-run, indicates no evidence of J-curve adjustment process. Unsurprisingly, the intra-industry trade seems to be an important factor that moderates the elasticities of trade balance to its determinants, especially to real effective exchange rate and domestic income. Overall results underline the importance of import-substitution capability besides the export-oriented production to ease the longstanding large trade deficits for Turkey.
\end{abstract}

Keywords: ARDL, bound testing, currency depreciation, intra-industry trade, J-curve, substitution, trade balance

\section{Introduction}

One of the traditional approaches modeling the balance of payments is the elasticities approach, which suggests exchange rate movements embody important impacts on the trade balance, shifting the demands for import and export to domestic substitutes. Determinants of trade flows and trade balance have always attracted researchers and policy makers in Turkey. This interest, centered in the close linkages between the trade balance and real exchange rate movements, has created a huge literature on Turkey's trade. Studies have had more data over the years since Turkey shifted to export-led industrialization strategy from import-substitution in 1980 (Gylfason \& Risager, 1984; Bahmani-Oskooee \& Alse, 1994; Kale, 2001). Historically, Turkey's total export performance seems to have fallen behind its total import in general, with a few exceptions in which Turkish lira was dramatically devaluated. After experiencing severe banking and currency crises in November 2000 and February 2001, Turkey abandoned the fixed exchange rate regime and let exchange rates freely float. After this critical decision, the interest in the exchange rate and trade balance relationship for Turkey has not diminished; on the contrary, it has increased by examining the effect of unpredictable currency depreciations on the export and more generally the trade balance performance (Akbostanci, 2004; Yazici, 2006; Halicioglu, 2008; Bahmani-Oskooee \& Kutan, 2009). Studies seem to have been more interested in investigating whether the Marshall-Lerner (M-L) condition holds or J-curve adjustments process exists.

Recently, some studies, however, suggests that cross-border production linkages are expected to lower the exchange rate elasticity of trade balance since depreciation of national currency also raises the cost of imported contents and intermediates (Kharroubi, 2011; Ahmed et al., 2015). Supporting this premise, Turkey has been observed experiencing production and export transition from traditional agriculture and labor-intensive 
manufactures such as food and textile to medium-level technological ones mainly like machinery and motor vehicles over time since the late 1990s. This means its export structure is getting more competitive in the global final product markets but besides, it also implies to the mutual complementarity in production linkages and intermediates trade. Considered Turkey's high import dependency in its export, depreciation of Turkish lira is expected to become less effective in boosting export growth, especially manufacturing exports because of the density of cross-border production networks in these sectors. Even being true, this premise is subject to criticisms since it ignores the other track in the international trade pattern that intra-industry trade (IIT) has been increasing as well, over time. IIT means countries trade off similar goods simultaneously within the same industry. In this two-way trade pattern, countries are producing goods similar to their import baskets, that the relative price changes can shift the directions of the trade easily. Starting from the omitted link in the recent literature this study also points to the sensitivity moderating effect of IIT in case of Turkey's trade with OECD-member countries (Note 1). The rest of the study is organized as follows. Section 2 presents the theoretical framework and a summary survey of the current literature on Turkey. Section 3 introduces the data sets and model. Section 4 consists of the empirical approach and analysis process. Section 5 demonstrates the empirical results and finally section 6 has the conclusion and discussion.

\section{Theoretical Framework and Related Evidence}

\subsection{Marshall-Lerner Condition and J-Curve Adjustment}

Traditional elasticities approach predicts that the devaluation of a national currency improves this country's trade balance making its export bundle relatively cheaper in the foreign markets and import bundle more expensive in the domestic market. Even introduced by Bickerdike (1920) initially, this simple relationship was popularized by Marshall (1923) and Lerner (1944). In their approach, for the success of devaluation in a country, the sum of the absolute values of price elasticities of imports $\left(e_{m}\right)$ and exports $\left(e_{x}\right)$ demands should be greater than unitary, when initially trade is balanced and supply elasticities are infinite. The elasticity requirement that was later called Marshall-Lerner (M-L) condition, can also be proved mathematically. When nominal exchange rate (NER) is expressed as the local currency per the foreign currency, and $P$ and $P f$ denote domestic and foreign price levels, respectively, real exchange rate $(R E R)$ can be formulated as in the equation 1.

$$
R E R=N E R(P f / P)
$$

When $Y, Y f, E X$, and $I M$ refer to domestic income, foreign income, export and import, respectively, net export $(N E X)$ of a country, which initially has a balanced trade, can be expressed in terms of national currency as in the equation 2 .

$$
N E X(R E R, Y, Y f)=E X(R E R, Y f)-R E R(I M(R E R, Y))=0
$$

Taken the derivatives in equation- 2 with respect to $R E R$, and rearranged dividing by $I M$, the condition that leads to an improvement (deterioration) in the NEX when RER increases (decreases) is expressed as in the equation 3.

$$
\frac{\partial(N E X)}{\partial(R E R)} \frac{1}{I M}=\frac{\partial(E X)}{\partial(R E R)} \frac{1}{I M}-1-\frac{R E R}{I M}\left(\frac{\partial(I M)}{\partial(R E R)}\right)>0
$$

Considered the assumption that trade is balanced initially, $E X=I M(R E R), 1 / I M=R E R / E X$, substituting it into the equation-3 and rearranging, we have the final expression of M-L condition in the equation 4.

$$
\underbrace{\frac{\partial(N E X)}{\partial(R E R)} \frac{R E R}{E X}}_{e}=\underbrace{\left(\frac{\partial(E X)}{\partial(R E R)} \frac{R E R}{E X}\right)}_{e_{x}}+\underbrace{\left|\frac{\partial(I M)}{\partial(R E R)} \frac{R E R}{I M}\right|}_{e_{m}}-1>0
$$

Elasticities approach and M-L condition have been tested later by numerous scholars who have contributed to related huge literature considering some cases where the original assumptions are not met, such as initial trade deficit or surplus, limited supply elasticity, sticky prices, etc. (Hirschman, 1949; Devereux, 2000; Bahmani-Oskooee \& Ratha, 2004). Some empirical evidence underlines the necessities for considering the different exchange rate regimes, countries' development and industrialization levels, resource endowments, intermediate trades, etc. while investigating the relationship between trade balance and exchange rate (Gylfason \& Risager, 1984; Bailliu \& Bouakez, 2004; Eicher et al., 2009; Kharroubi, 2011; Ahmed et al., 2015; Pancaro \& Saborowski, 2015).

Main critiques against original elasticities approach and M-L condition have centered on the negligence of the time dimension that a real devaluation (or depreciation) of home currency is not immediately followed by trade balance improvement. Besides, it gets worse in the short-run before getting better in the long-run. This lagged 
adjustment path that resembles the letter $\mathrm{J}$, was first introduced theoretically as the $\mathrm{J}$-curve phenomenon by Magee (1973), who put forward the binding currency contracts and pass-through effects as possible reasons.

The trade balance of a country can be directly or indirectly affected by numerous supply- and demand-side factors. Demand-side factors are mainly on accessing to foreign markets, measured and proxied by openness, liberalization and globalization. Supply-side factors are physical and human capital stocks, infrastructure and logistic performance, business environment, wage level and labor cost, domestic and foreign incomes, demand and supply elasticities, government expenditures, natural resources endowment, macroeconomic indicators (inflation, interest rate, growth $e t c$.), foreign direct investment, multinational activities, and institutional factors are among many others. There is now an immense literature on both developed and developing countries based on the total or bilateral trade data and/or sectoral aggregated or disaggregated basis (see Bahmani-Oskooee \& Ratha, 2004; Bahmani-Oskooee \& Hegerty, 2010; Bahmani, Harvey, \& Hegerty, 2013, for a detailed survey).

There are studies covering or specifically examining Turkey's trade balance. Existing findings from the empirical literature on Turkey are diverse depending on partner coverage, sample periods, sectoral disaggregation and econometric methods. According to the available data characteristics, cointegration-based approaches are seen the most common procedures in the studies. As previously mentioned, main attempts in the literature are examining M-L condition and J-curve phenomenon. Some support the M-L condition in both the short and the long-run, while the others found J-curve adjustment process. There are also some studies concluding no significant results or different adjustment patterns such as S-curve.

Gylfason and Risager (1984), grouped countries as developing and industrialized ones, and found $10 \%$ devaluation improved current account on an average by $1.2 \%$ and $2.2 \%$ of their national income for developing and developed countries, respectively. As a developing country, this net effect was $0.7 \%$ for Turkey that referred to under-effect compared to the average of developing countries. Brada et al. (1997) found that exchange rate policy was capable of controlling the trade balance effectively in the 1980s and early 1990s for Turkey. Using quarterly data for the period of 1984-1996 and following Johansen cointegration approach, Kale (2001) concluded that real depreciation improves the trade balance in the long-run. Results also support J-curve evidence that this improvement starts with a lag of about one year. Employing error correction model and impulse-response function techniques for the period 1987-2000, Akbostanci (2004) found that M-L condition was satisfied in the long-run. However, there was not a strong evidence supporting J-curve. Kimbugwe (2006) applied several analysis instruments on both aggregated and disaggregated data for the period of 1960 and 2000 annually. Results were not supporting the J-curve hypothesis for the bilateral trade between Turkey and its 9 major trading partners.

Yazic1 (2006), tested whether J-curve hypothesis holds in Turkey's agricultural sectors, based on the quarterly data covering the period from 1986.QI to 1998.QIII. Results rejected the J-curve pattern finding a different adjustment path that after devaluations, trade balance initially improved, then worsened, and later improved again in agricultural sectors. Halicioglu (2008) used quarterly bilateral trade data of Turkey's 13 trade partners for the period of 1985-2005 and applied ARDL bound testing approach. The empirical results indicated that even there was no J-curve effect found in the short-run; the real depreciation of the Turkish lira had a positive impact on Turkey's trade balances in its trades with the United Kingdom and the United States in the long-run. Similarly, Celik and Kaya (2010) analyzed Turkey's bilateral trade dynamics with respect to a panel of 7 countries. Employing panel cointegration techniques, they found that the relationships between devaluation/depreciation of Turkish lira and trade balances were country-specific.

One of the studies that consider the effect of oil prices as we do is those of Irhan, Alacahan and Korap (2011). They followed ARDL bounds testing approach and found that real depreciations improved the trade balance strongly. Their results indicate that domestic and foreign incomes have respectively negative and positive effects on the trade balance as theoretically expected. They also found no significant effect of crude oil prices to the trade balance. Yazici and Islam (2014) investigated these effects on the bilateral trade balances of Turkey with 15 European Union member countries. Again, they followed the bounds testing approach to the cointegration and the error correction modeling using quarterly data spanning from 1982 to 2001. Their results concluded no evidence of J-curve in any of Turkey's bilateral trades. However, real depreciation of Turkish lira improved the trade balance of Turkey with some individual countries in the long-run. Akkay (2015) investigated S-curve evidence in Turkey's trade with different aggregate levels for the quarterly period of 2003 and 2012. The results showed that there is a weak S-curve relation with the rest of the world and the developing countries. On the other hand, they found a strong relation in Turkey's trade with the developed countries. At the bilateral level, S-curve relations were strong in the 14 out of 20 cases. 
Studies in the related literature seem to be restricted to just searching M-L condition and J-curve evidence ignoring what these relationships are also affected by. One of the factors, in this study, is intra-industry trade development that, we also purpose to attract researchers' attention to the intra-industry trade while interpreting the results. For this purpose, we empirically show how the intra-industry trade level affects the relationships between trade balance and its determinants, especially exchange rate and domestic income. By doing so, we can find out some possible explanations to why Turkey's trade balance has not improved significantly given the considerable depreciation that Turkish lira has been experiencing recently.

\subsection{Intra-Industry Trade and Its Moderating Roles}

One of the main factor determining the success of devaluation is the availability of alternative goods that can replace the imported goods in the domestic market. This substitutability can be measured by intra-industry trade (IIT) that show the extent to which a country simultaneously exports and imports similar types of goods. Researchers have been interested in investigating the reasons of increasing IIT among countries especially in those of developed ones since 1970 (Grubel \& Lloyd, 1975; Krugman, 1990; Brulhart, 2009). Main explanations for IIT have concentrated on economies of scale and increasing returns, imperfect competition, product differentiation, specialization in different production stages, foreign direct investment flows and the activities of multinational enterprises (Davis, 1995; OECD, 2002; Brulhart, 2009). In this study, we compute Grubel and Lloyd (1975) index for Turkey as the proxy of its IIT level, adapting their methodology to our case similarly to OECD (2002). The index for the manufacturing (Note 2) sector $i$ between Turkey and OECD is computed by the ratio in the equation 5.

$$
I I T=G L_{i, T R \Leftrightarrow O E C D}=\left[\frac{\left(E X_{i}+I M_{i}\right)-\left|E X_{i}-I M_{i}\right|}{\left(E X_{i}+I M_{i}\right)}\right] .100
$$

Where $E X_{i}$ and $E M_{i}$ respectively refer to Turkey's exports and imports in the sector $i$ in its trade with OECD countries over one particular period, quarterly in our case. It was simpler to pretend all the OECD countries as one country. Then the sector-based indexes, calculated in SITC Rev. 3, 3-digits, are aggregated across $N$ industries, total manufactures in our case, using the formula in the equation-6. The aggregation bias caused by this restriction is not a serious problem since we computed trade-weighted averages based on the share of sub-sector $\underline{i}$ in total manufacturing as suggested by Brulhart (2009) (Note 3). In addition, this study concerns about total trade balance, not the sectoral ones specifically.

$$
I I T=G L_{T R \Leftrightarrow O E C D}=\sum_{i} \frac{\left(E X_{i}+I M_{i}\right)-\left|E X_{i}-I M_{i}\right|}{\left(E X_{i}+I M_{i}\right)} \cdot\left[\frac{\left(E X_{i}+I M_{i}\right)}{\sum_{i}\left(E X_{i}+I M_{i}\right)}\right] .100
$$

Grubel-Lloyd index can vary between 0 and 1 . If the index takes the maximum value of 1 , it means Turkey has only IIT that its exports quantity equals to the import quantity in the sector $i$. Conversely, when the index is 0 , it means Turkey has only one-way trade over the industry, i.e., it either exports or imports in the sector $i$ (Note 4). In fact, the latter case is consistent with the specialization patterns that neo-classical trade theories predict.

\section{Data Sets and the Model}

Today OECD has 34 members that account for three-quarters of world trade (OECD, 2016). As a member, Turkey has close political and economic relationships with the other OECD countries, especially with those of that are also European Union members. Historically, OECD countries' total share is more than half in Turkey's export and import as seen in Table 1. Figure 1 also illustrates the increasing pattern of IIT between Turkey and OECD.

The trade of Turkey with OECD countries has developed in a deficit dominant pattern. According to UN COMTRADE (2016) data, Turkey's main export commodities to OECD countries were mainly of traditional agriculture and labor-intensive goods such as food and textile for the pre-2000 period. This has started to change since the late 1990s that the share of medium-level technological manufactures mainly like machinery and motor vehicles in the OECD export has increased. Main commodities in Turkey's recent import basket from OECD countries, mostly European Union-15, are chemicals, accounting and computing machinery, electrical machinery, and transport equipment. 
Table 1. Trade between Turkey and OECD countries (1996-2015, selected years)

\begin{tabular}{lcccccc}
\hline Years & $\begin{array}{c}\text { Turkey's total } \\
\text { export, million U.S. } \\
\text { dollar }\end{array}$ & $\begin{array}{c}\text { Export to OECD } \\
\text { countries, million U.S. } \\
\text { dollar }\end{array}$ & $\begin{array}{c}\text { Share, \% } \\
\text { Turkey's total import, } \\
\text { million U.S. dollar }\end{array}$ & $\begin{array}{c}\text { Import from OECD } \\
\text { countries, million U.S. } \\
\text { dollar }\end{array}$ & $\begin{array}{c}\text { Share, } \\
\%\end{array}$ \\
\hline 2015 & 145,613 & 77,285 & 53.08 & 216,932 & 112,270 & 51.75 \\
2014 & 157,610 & 76,675 & 48.65 & 242,177 & 116,518 & 48.11 \\
2013 & 151,803 & 68,684 & 45.25 & 251,661 & 124,207 & 49.35 \\
2012 & 152,462 & 66,290 & 43.48 & 236,545 & 113,724 & 48.08 \\
2011 & 134,907 & 67,114 & 49.75 & 240,842 & 121,328 & 50.38 \\
2010 & 113,883 & 57,394 & 50.40 & 185,544 & 94,163 & 50.75 \\
2008 & 132,027 & 66,407 & 50.30 & 201,964 & 98,891 & 48.96 \\
2005 & 73,476 & 45,847 & 62.40 & 116,774 & 67,238 & 57.58 \\
2002 & 36,059 & 24,432 & 67.76 & 51,554 & 33,608 & 65.19 \\
1999 & 26,587 & 18,674 & 70.24 & 40,671 & 28,690 & 70.54 \\
1996 & 23,224 & 14,712 & 63.35 & 43,627 & 31,318 & 71.79 \\
$1996-2015$ & $1,663,715$ & 895,367 & 53.82 & $2,636,120$ & $1,394,780$ & 52.91 \\
\hline
\end{tabular}

Source: TurkStat-Turkish Statistical Institute (2016).

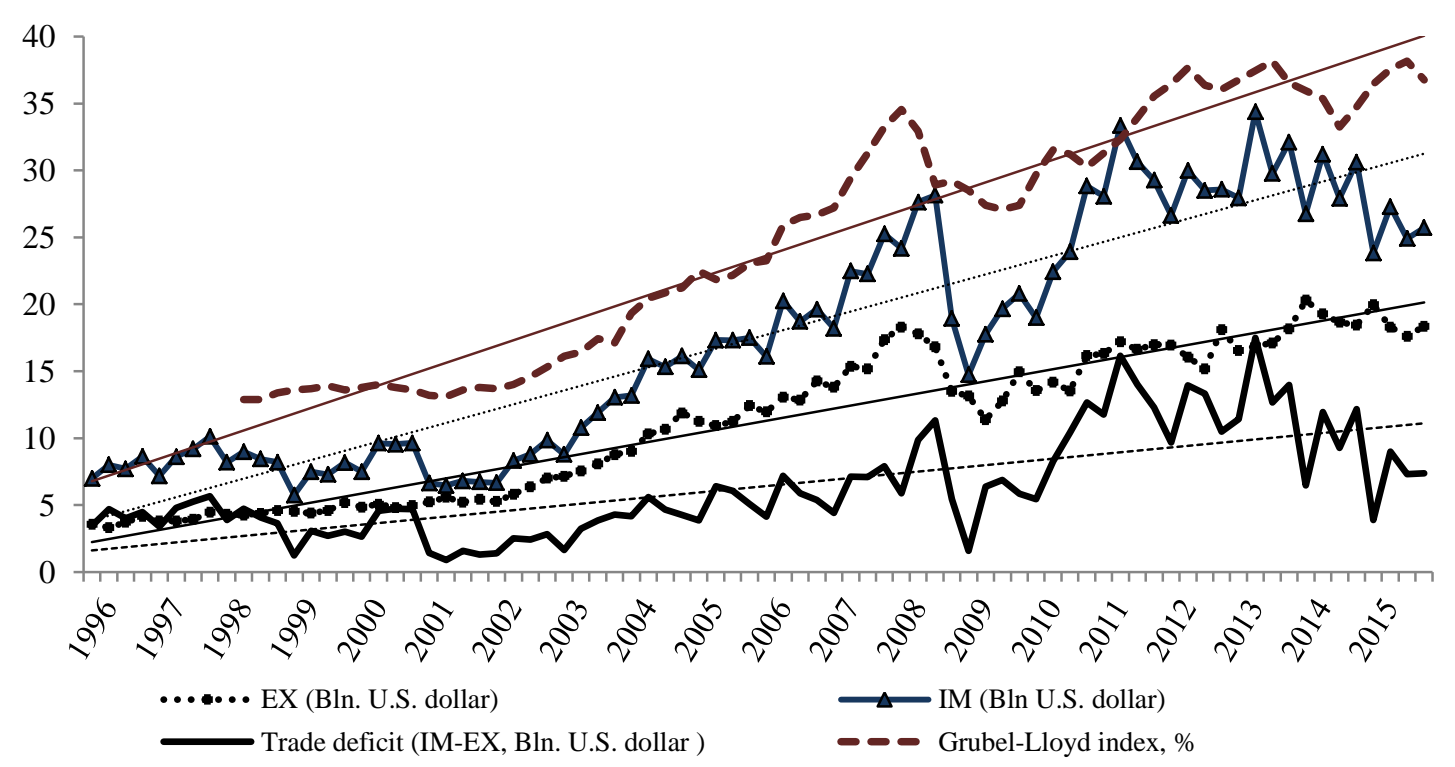

Figure 1. Plot of the indicators for Turkey's OECD trade and intra-industry trade

We use quarterly data modified from different sources as seen in Table 2. There are several measurements of trade balance. We used the ratio of exports to imports as trade balance variable following Rose and Yellen (1989). This specification, showing the import compensation ratio of export as well, enables to transform the variables in logarithmic form and hence allows the coefficients to be interpreted as elasticities (Narayan, 2006). All the series are indexed as 2010.QI=100.

Table 2. Variables, descriptions, and sources

\begin{tabular}{cccc}
\hline Series & Variables & Descriptions & Sources \\
\hline Trade balance & InTB & $\begin{array}{l}\text { Dependent variable } \\
\text { The ratio of Turkey's exports to its imports in the trade with 33 } \\
\text { OECD countries. Manufacturing only. } \\
\text { Independent variables }\end{array}$ & $\begin{array}{c}\text { Author's calculations from } \\
\text { UN COMTRADE, 2016 }\end{array}$ \\
$\begin{array}{l}\text { Real effective } \\
\text { exchange rate }\end{array}$ & InREER & $\begin{array}{l}\text { Based on consumer price index. Weighed by the shares of trade } \\
\text { partners in manufacturing trade. Periodic average. }\end{array}$ & $\begin{array}{c}\text { Author's calculations from } \\
\text { IMF (2016) }\end{array}$ \\
\hline
\end{tabular}




\begin{tabular}{|c|c|c|c|}
\hline Domestic income & $\ln Y$ & Turkey's gross domestic product by total expenditures. & OECD (2016) \\
\hline Foreign income & $\ln Y f$ & $\begin{array}{l}\text { OECD countries' gross domestic product by total expenditures. } \\
\text { Country averages. }\end{array}$ & OECD (2016) \\
\hline Oil prices & $\ln O P$ & $\begin{array}{l}\text { Daily unleaded gasoline pumps price in main industrial cities of } \\
\text { Turkey. Current market price as U.S. dollar per liter. Periodic } \\
\text { averages. }\end{array}$ & $\begin{array}{l}\text { Author's calculations from } \\
\text { OPET, } 2016\end{array}$ \\
\hline Intra-industry trade & $\ln I I T$ & $\begin{array}{l}\text { Grubel-Lloyd index. Manufacturing only. Calculated SITC Rev. } \\
\text { 3, 3-digits level. Weighted by sectoral shares. Sectoral averages. }\end{array}$ & $\begin{array}{l}\text { Author's calculations from } \\
\text { UN COMTRADE (2016) }\end{array}$ \\
\hline
\end{tabular}

It is can be tracked from Figure 2 that the Turkish lira has a real appreciation trend for the period 1998-2007. On the contrary, for the period of 2008-2015, it has a depreciation trend against the basket of the currencies of OECD countries weighted by their shares of the trade with Turkey. Sharp decline in 2001.Q1 and Q2 are the first shocks of abandoning the fixed exchange rate system in February 2001.
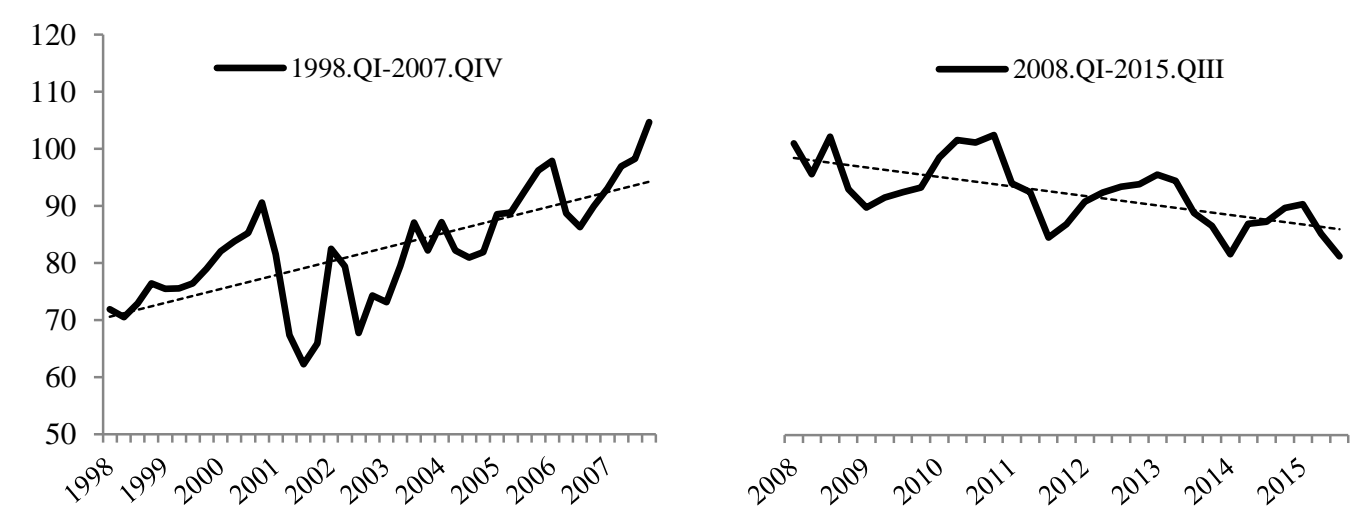

Figure 2. Changes in the real value of Turkish lira, 2010.QI=100

This study's empirical structure is based on Goldstein and Khan's (1985) imperfectly substituted trade balance model and its variations. Originally, this model embodies the income and price effects, as well. In their approach, neither imports nor exports are perfectly substitutes the domestic goods; domestic income negatively affects trade balance while foreign income and real exchange rate do positively. This weak-substitution model was further discussed by Edwards and Alves (2006), and Edwards and Garlick (2008). The regression model of the study is in the equation 7 .

$$
\begin{gathered}
\ln T B_{i t}=\beta_{0}+\beta_{1} \ln R E E R_{t}+\beta_{2} \ln Y_{t}+\beta_{3} \ln Y f_{t}+\beta_{4} \ln O P_{t}+\left(\beta_{5} \ln I I T_{t}\right)+u_{t} \\
(i=1,2, \ldots, 5 ; \quad t=1998 . Q I, \ldots, 2015 . Q I I I)
\end{gathered}
$$

All the data variables were converted into natural logarithms that help in having a normal distribution and homoscedastic error term. It can also reduce the heteroscedasticity (Sinha, 2007, pp. 94-95, p. 158). After transforming this model into the ARDL form, first it will be estimated without IIT in order to explore the pure relationships between $T B$ and its core determinants. Then $I I T$ will be added to the model to determine whether IIT moderates these relations.

Following the existing literature, after a change in the real effective exchange rate (REER), if M-L condition is satisfied $\beta_{l}$ will be positive in both the short-run and the long-run. However, if trade balance $(T B)$ is adjusted according to J-curve pattern, $\beta_{I}$ will be negative in the short-run but positive in the long-run. Considered Goldstein and Khan's (1985) model, domestic income $(Y)$ growth leads to increasing in import demand that in turn worsens the trade balance. However, growth in domestic income can also raise the production of import substitution goods, so Turkey can import less as its income increases and consequently trade balance can improve. Similar explanations are true for foreign income ( $Y f)$ in trade partners' cases. Therefore, $\beta_{2}$ and $\beta_{3}$ can also be positive or negative depending on the relative net effect of supply and demand-side factors.

The other variable is oil prices $(O P)$ that is expected to affect export performance negatively. The effect of $O P$ to the current account and trade balance are among main research interests in Turkey, a country highly dependent 
on energy imports. Lower energy import prices are expected to reduce Turkey`s large current deficit. The concern in this study is production side that cheap energy inputs are expected to boost the cost-competitiveness of export. Studies commonly use international crude oil prices for this variable (e.g. Korhonen \& Ledyaeva, 2010; Irhan et al., 2011; Narayan et al., 2014). However, this measure does not seem to reflect real cost, since the exchange rate movements and high local taxes change the prices in domestic markets, as in the Turkey's case. It has been observed that even oil prices have been falling globally from the second half of 2014 to the end of 2015, this downward trend has not seen fully reflected to the pump prices in Turkey. Therefore, in this study, we computed real market prices of gasoline for main industrial cities in Turkey, as sold including all taxes. This is the other feature of the study that makes it different. It is converted to the U.S. dollar using current nominal exchange rates and then indexed to 2010.Q1=100 for data harmonization.

The last variable in the equation-7 is IIT that is expected to change the magnitudes of the effects of independent variables. In the manufacturing sectors, IIT levels are relatively high compared to primary commodities (see Brulhart, 2009, for details). This is expected to increase REER sensitivity of trade balance (Kharroubi, 2011). In this study, IIT represents the availability of the alternatives for relatively more expensive imports in the domestic market and more expensive products of other countries in the markets of Turkey's trade partners after the depreciation of the Turkish lira in Turkey. So, when we added IIT to the model, $\beta_{5}$ is expected to be significantly positive and to reduce the values of coefficients compared to those of estimated without IIT. Because the opposite effect can occur, i.e., after the appreciation, relatively cheaper imports can replace the more expensive domestic products, $\beta_{5}$ can also be negative. The latter case can impel Turkey to enforce complementary trade policies to retard the demand shift. These policy options also have some directions for further studies.

\section{Empirical Approach and Analysis Process}

In order to determine appropriate analysis procedure to follow, first we checked each time series for stationarity using Augmented Dickey and Fuller (1981) (ADF) and Kwiatkowski, Phillips, Schmidt and Shin (1992) (KPSS) unit roots tests. Unit roots test results seen in Table-4 indicate that the variables have different integration orders. ARDL bounds testing procedures, developed by Pesaran and Shin (1999) and Pesaran, Shin and Smith (2001), let the variables integrated in order 1, i.e. $I(1)$, or the level, i.e. $I(0)$, be analyzed. Since no variable is $I(2)$, the study applies the ARDL bounds testing approach that has a number of advantages over conventional cointegration tests: It does not require variables to be integrated of the same order, unless there is $I(2)$. The variables can have different lag lengths in the model. It can be applied to relatively smaller sample size as in our case. The short-run and the long-run effects between variables can be estimated simultaneously without losing any information.

In order to follow the ARDL bounds testing procedure, the regression model in equation- 7 is transformed to error correction form as seen in equation-8.

$$
\begin{aligned}
D \ln (T B)_{t}= & \alpha_{0}+\sum_{i=1}^{L} \omega_{i} D \ln (T B)_{t-i}+\sum_{i=0}^{L} \theta_{i} D \ln (R E E R)_{t-i}+\sum_{i=0}^{L} \lambda_{i} D \ln (Y)_{t-i}+\sum_{i=0}^{L} \varphi_{i} D \ln (Y f)_{t-i}+\sum_{i=0}^{L} \Phi_{i} D \ln (O P)_{t-i} \\
& +\sum_{i=0}^{L} \partial_{i} D \ln (I I T)_{t-i}+\phi_{1} \ln (T B)_{t-1}+\phi_{2} \ln R E E R_{t-1}+\phi_{3} \ln (Y)_{t-1}+\phi_{4} \ln (Y f)_{t-1}+\phi_{5} \ln (O P)_{t-1}+\phi_{6} \ln (I I T)_{t-1}+\varepsilon_{t}
\end{aligned}
$$

Where, all the variables are as previously defined. $D$ is the first-difference operator, $L$ is the optimal lag length, $t$ is the time trend and $\varepsilon_{t}$ is the white noise residuals. In the ARDL model, the Schwarz Bayesian Criterion (SC) and the Akaike Information Criterion (AIC) are widely used to determine the optimum lag order. However, Pesaran and Shin (1999) indicate that SC-based ARDL estimators perform better than AIC-based ones and SC is a consistent model selection criterion in most experiments.

When processing the ARDL bounds testing approach, first the existence of a long-run relationship between variables is tested using the $F$-test for the joint significance of lagged level variables. The null hypothesis of no cointegration among variables in equation- 8 is $\left(\mathrm{H}_{0}: \phi_{1}=\phi_{2}=\cdots=\phi_{6}=0\right)$ against the alternative hypothesis $\left(\mathrm{H}_{1}: \phi_{1} \neq \phi_{2} \neq \cdots \neq \phi_{6} \neq 0\right)$. For the $F$-test, Pesaran et al. (2001) generated asymptotic critical values of lower and upper thresholds, assuming all the variables are purely $I(0)$ for the lower bound, and $I(1)$ for the upper bound.

The value of the $F$-test depends on the number of the independent variables $(k)$, their integration orders, i.e. $I(0)$ or $I(1)$, and whether the model has intercept, trend or both processes. The critical values those of Pesaran et al. (2001) are more suitable for large sample sizes. Narayan (2004) argues that these critical values cannot be used for small sample sizes. Given a relatively small size of our study with 71 observations, we consider the critical values reported by Narayan (2004), which based on sample size between 30 and 80 . If the $F$-test statistic exceeds the upper critical values, the existence of the long-run relationship is verified, rejecting the null hypothesis of no 
cointegration. Otherwise, i.e., when the test statistic is below the upper critical values, the existence of the cointegration is rejected. If it lies between the bounds, the relationship is inconclusive.

When the $F$-test concludes a long-run relationship, then the long-run coefficients specified in the equation- 9 are estimated.

$$
\begin{aligned}
\ln (T B)_{t}= & \alpha_{1}+\sum_{i=1}^{L} \phi_{1 i} \ln (T B)_{t-i}+\sum_{i=0}^{L} \beta_{1 i} \ln (R E E R)_{t-i}+\sum_{i=0}^{L} \theta_{1 i} \ln (Y)_{t-i}+\sum_{i=0}^{L} \lambda_{1 i} \ln (Y f)_{t-i} \\
& +\sum_{i=0}^{L} \Upsilon_{1 i} \ln (O P)_{t-i}+\sum_{i=0}^{L} \Phi_{1 i} \ln (I I T)_{t-i}+\varepsilon_{t}
\end{aligned}
$$

In order to have an idea how to set the maximum lag order, we compared $S C$ and $A I C$ in the unrestricted vector autoregression (VAR). Finally, the error correction model under the ARDL framework can be specified as in the equation-10. Estimating this error correction model allows us to have the short-run dynamics of the relationships between trade balance and its potential determinants.

$$
\begin{aligned}
D \ln (T B)_{t}= & \alpha_{2}+\sum_{i=1}^{L} \phi_{2 i} D \ln (T B)_{t-i}+\sum_{i=0}^{L} \theta_{2 i} D=D \ln (R E E R)_{t-i}+\sum_{i=0}^{L} \lambda_{2 i} D \ln (Y)_{t-i} \\
& +\sum_{i=0}^{L} \varphi_{2 i} D \ln (Y f)_{t-i}+\sum_{i=0}^{L} \varpi_{2 i} D \ln (O P)_{t-i}+\sum_{i=0}^{L} \pi_{2 i} D \ln (I I T)_{t-i}+\Omega E C M_{t-1}+\rho_{t}
\end{aligned}
$$

In the equation-10,ECM ${ }_{t-1}$ is the error correction term and defined as in the equation-11.

$$
\begin{aligned}
E C M_{t}= & \ln (T B)_{t}-\alpha_{1}-\sum_{i=1}^{L} \phi_{1 i} \ln (T B)_{t-i}-\sum_{i=0}^{L} \partial_{1 i} \ln (R E E R)_{t-i}-\sum_{i=0}^{L} \theta_{1 i} \ln (Y)_{t-i} \\
& -\sum_{i=0}^{L} \lambda_{1 i} \ln (Y f)_{t-i}-\sum_{i=0}^{L} \phi_{1 i} \ln (O P)_{t-i}-\sum_{i=0}^{L} \omega_{1 i} \ln (I I T)_{t-i}
\end{aligned}
$$

To ensure the convergence of the dynamics to long-run equilibrium, the sign of the coefficient $(\Omega)$ for the lagged error correction term $\left(E C M_{t-1}\right)$ is required to be negative and significant (Kyophilavong et al., 2013).

\section{The Empirical Results}

Table-3 displays the descriptive statistics and pairwise correlations of the variables. Jarque-Bera normality test confirms that series are normally distributed at 5\% level. All the variables, except $Y$, are positively correlated with $T B$. In general, the correlations between $T B$ and its determinants are weak.

Table 3. Descriptive statistics and pairwise correlation, $(n=71)$

\begin{tabular}{lcccccc}
\hline & $\ln T B$ & $\ln R E E R$ & $\ln Y$ & $\ln Y f$ & $\ln O P$ & $\ln I I T$ \\
\hline Mean & 4.177 & 4.438 & 4.472 & 4.540 & 3.989 & 4.332 \\
Median & 4.174 & 4.458 & 4.514 & 4.583 & 4.342 & 4.470 \\
Maximum & 4.491 & 4.626 & 4.830 & 4.671 & 4.917 & 4.813 \\
Minimum & 3.856 & 4.107 & 4.146 & 4.321 & 1.686 & 3.728 \\
Std. Dev. & 0.145 & 0.118 & 0.220 & 0.099 & 0.923 & 0.392 \\
Skewness & -0.159 & -0.418 & -0.043 & -0.529 & -0.915 & -0.349 \\
Kurtosis & 2.263 & 2.856 & 1.562 & 2.061 & 3.183 & 1.775 \\
Jarque-Bera & 1.370 & 2.305 & 4.311 & 5.124 & 5.701 & 1.253 \\
Probability & 0.504 & 0.316 & 0.116 & 0.077 & 0.058 & 0.535 \\
\hline $\ln T B$ & 1.000 & & & & & \\
$\ln R E E R$ & 0.268 & 1.000 & & & & \\
$\ln Y$ & -0.254 & 0.689 & 1.000 & & & \\
$\ln Y f$ & 0.163 & 0.742 & 0.921 & 1.000 & & \\
$\ln O P$ & 0.235 & 0.653 & 0.864 & 0.939 & 1.000 & \\
$\ln I I T$ & 0.497 & 0.353 & 0.632 & 0.608 & -0.173 & \\
\hline
\end{tabular}

ADF and KPSS unit roots tests results are reported in Table-4 show that there is a mixture of $I(1)$ and $I(0)$ of the variables. 
Table 4. Results of unit root tests

\begin{tabular}{|c|c|c|c|c|c|}
\hline \multirow[b]{2}{*}{ Variables } & \multicolumn{2}{|c|}{ ADF } & \multicolumn{2}{|c|}{ KPSS } & \multirow{2}{*}{$\begin{array}{c}\text { Inference } \\
5 \% \\
\end{array}$} \\
\hline & Intercept & Trend \& intercept & Intercept & Trend \& intercept & \\
\hline $\ln T B$ & $-5.024 *$ & $-5.105^{*}$ & $0.217^{*}$ & 0.166 & $\mathrm{I}(0)$ or $\mathrm{I}(1)$ \\
\hline$D \ln T B$ & $-4.549 *$ & $-4.502^{*}$ & $0.201 *$ & $0.143^{*}$ & $\mathrm{I}(0)$ \\
\hline InREER & -2.652 & -2.692 & 0.705 & 0.214 & $\mathrm{I}(1)$ \\
\hline$D \ln R E E R$ & $-7.380 *$ & $-7.389 *$ & $0.296^{*}$ & $0.140^{*}$ & $\mathrm{I}(0)$ \\
\hline $\ln Y$ & 0.227 & 3.089 & 1.069 & $0.076^{*}$ & $\mathrm{I}(0)$ or $\mathrm{I}(1)$ \\
\hline$D \ln Y$ & $-6.216^{*}$ & $-6.199 *$ & $0.100^{*}$ & $0.075^{*}$ & $\mathrm{I}(0)$ \\
\hline $\operatorname{LnYf}$ & -1.941 & -2.011 & 1.024 & 0.248 & $\mathrm{I}(1)$ \\
\hline$D \ln Y f$ & $-3.851^{*}$ & $-4.075^{*}$ & $0.364 *$ & $0.074 *$ & $\mathrm{I}(0)$ \\
\hline $\ln O P$ & $-5.207 *$ & -2.074 & 1.077 & $0.111 *$ & $\mathrm{I}(0)$ or $\mathrm{I}(1)$ \\
\hline$D \ln O P$ & $-4.639 *$ & $-6.362 *$ & $0.166^{*}$ & $0.084 *$ & $\mathrm{I}(0)$ \\
\hline $\operatorname{lnIIT}$ & -1.080 & -1.461 & 1.051 & 0.178 & $\mathrm{I}(1)$ \\
\hline DlnIIT & $-6.046^{*}$ & -6.070 & $0.157 *$ & $0.095^{*}$ & $\mathrm{I}(0)$ \\
\hline
\end{tabular}

Note. $5 \%$ critical values are -2.904 (with trend) and -3.476 (with trend and intercept) for ADF test statistics and 0.463 (with trend) and 0.146 (with trend and intercept) for KPSS test statistics. * Stationary at $5 \%$ level.

Then equation-8 is estimated to examine the long-run relationships among the variables, in two stages: Without InIIT and then with InIIT. We compared SC and AIC in the unrestricted VAR that they indicated lag orders 1 and 5, respectively. After setting the maximum length to 1 and 5, we have the result indicate that the best fitting models, which make the $S C$ and $A I C$ minimum are ARDL $(1,0,0,0,0)$ for $S C$ and ARDL $(4,2,5,4,1)$ for AIC. When InIIT is added, the best fitting models for the criteria are $\operatorname{ARDL}(1,0,0,0,0,0)$ and $\operatorname{ARDL}(4,2,5,4,5,4)$ for $S C$ and $A I C$, respectively.

In this study's case, $S C$ was quite meticulous in comparison with to $A I C$ while evaluating the possible models. However, it is seen that over-fitting problem can arise from the AIC-based model selection. Hence, analyses are processed based on the both model selections, which also helps in comparing the results. Further, main stability and residual diagnostic tests like serial correlation, normality, heteroscedasticity, cumulative sum (CUSUM) and sum of squares (CUSUMSQ) tests are applied to check the estimation robustness. Calculated $F$-statistics based on $S C$ and $A I C$ are separately displayed in Table 5.

We can observe that estimation results of the $F$-statistics for both AIC- and SC-based models exceed the upper critical values at $1 \%$ level. In fact, they are also greater than those upper critical values that Pesaran and Shin (1999) and Pesaran et al. (2001) generated.

Table 5. Bound testing results and cointegration relationship

\begin{tabular}{|c|c|c|c|c|c|c|c|c|}
\hline \multicolumn{9}{|c|}{ Without lnIIT } \\
\hline$F$-statistic value & \multicolumn{8}{|c|}{ Bound Critical Values* $(n=71 ; k=4)$} \\
\hline$S C$-ARDL & \multicolumn{4}{|c|}{ with intercept and no trend } & \multicolumn{4}{|c|}{ with intercept and trend } \\
\hline$(1,0,0,0,0)=\mathbf{8 . 7 8 1}$ & \multicolumn{2}{|c|}{$1 \%$} & \multicolumn{2}{|c|}{$5 \%$} & \multicolumn{2}{|c|}{$1 \%$} & \multicolumn{2}{|c|}{$5 \%$} \\
\hline$A I C-A R D L$ & $\mathrm{I}(0)$ & $\mathrm{I}(1)$ & $\mathrm{I}(0)$ & $\mathrm{I}(1)$ & $\mathrm{I}(0)$ & $\mathrm{I}(1)$ & $\mathrm{I}(0)$ & $\mathrm{I}(1)$ \\
\hline$(4,2,5,4,1)=\mathbf{7 . 7 9 5}$ & 3.608 & 4.860 & 2.725 & 3.718 & 4.098 & 5.570 & 3.022 & 4.256 \\
\hline \multicolumn{9}{|c|}{ With lnIIT } \\
\hline$F$-statistic value & \multicolumn{8}{|c|}{ Bound Critical Values* $(\mathrm{n}=71 ; \mathrm{k}=5)$} \\
\hline$S C-A R D L$ (lag:1) & \multicolumn{4}{|c|}{ with intercept and no trend } & \multicolumn{4}{|c|}{ with intercept and trend } \\
\hline$(1,0,0,0,0,0)=8.597$ & \multicolumn{2}{|c|}{$1 \%$} & \multicolumn{2}{|c|}{$5 \%$} & \multicolumn{2}{|c|}{$1 \%$} & \multicolumn{2}{|c|}{$5 \%$} \\
\hline AIC-ARDL (lag:5) & $\mathrm{I}(0)$ & $\mathrm{I}(1)$ & $\mathrm{I}(0)$ & $\mathrm{I}(1)$ & $\mathrm{I}(0)$ & $\mathrm{I}(1)$ & $\mathrm{I}(0)$ & $\mathrm{I}(1)$ \\
\hline$(4,2,5,4,5,4)=\mathbf{7 . 8 7 8}$ & 3.373 & 4.717 & 2.564 & 3.650 & 3.747 & 5.285 & 2.788 & 4.073 \\
\hline
\end{tabular}

Note. * Critical values are extracted from Narayan (2004).

Consequently, $F$-statistics strongly infer the existence of the cointegration relationship between the variables. After estimating equation-9, we have the results of Table-6. 
Table 6. Estimated long-run coefficients (dependent variable: $\ln T B_{t}$ )

\begin{tabular}{|c|c|c|}
\hline \multicolumn{3}{|c|}{ without $\ln I I T$} \\
\hline Variables & $S C-A R D L:(1,0,0,0,0)$ & AIC-ARDL: $(4,2,5,4,1)$ \\
\hline $\ln R E E R_{t}$ & $0.751[3.897]^{*}$ & $1.948[2.469]^{*}$ \\
\hline $\ln Y_{t}$ & $-1.377[-6.454]^{*}$ & $-1.469[-4.662]^{*}$ \\
\hline $\ln Y f_{t}$ & $4.376[4.668]^{*}$ & $5.732[3.001]^{*}$ \\
\hline $\ln O P_{t}$ & $-0.087[-1.359]$ & $0.013[0.089]$ \\
\hline Constant $_{t}$ & $-5.853[-1.979]$ & $-6.666[-1.332]$ \\
\hline \multicolumn{3}{|c|}{ with $\ln I I T$} \\
\hline & $S C-A R D L:(1,0,0,0,0,0)$ & AIC-ARDL:(4,2,5,4,5,4) \\
\hline $\ln R E E R_{t}$ & $0.575[-3.742]^{*}$ & $1.296[2.320]^{*}$ \\
\hline $\ln Y_{t}$ & $-1.129[-4.627]^{*}$ & $-0.689[-6.635]^{*}$ \\
\hline $\ln Y f_{t}$ & $4.381[4.190]^{*}$ & $5.664[3.303]$ \\
\hline $\ln O P_{t}$ & $-0.085[-1.330]$ & $0.102[0.829]$ \\
\hline $\operatorname{lnIIT}$ & $0.413[2.134]^{*}$ & $-0.458[-2.811]^{*}$ \\
\hline Constant $_{t}$ & $-4.371[-1.495]$ & $-3.204[-1.231]$ \\
\hline
\end{tabular}

Notes. $t$ statistics are in the [brackets]. * denotes significance at $5 \%$ levels.

The results in the first row of the Table 6 show that in both models REER, $Y$ and $Y f$ are important determinants of the trade balance in the long-run. 1\% depreciation (appreciation) of the Turkish lira yields to an improvement (deterioration) in the $T B$ by $0.75 \%$ for the $S C$-based model and $1.95 \%$ for the $A I C$-based model. This evidence strongly suggests that the M-L condition holds for the long-run. Differences of coefficient magnitudes between models prove once again that the results are very sensitive to lag length and hence, right selection of criteria is very important in the ARDL framework. We suggest comparing both results as we have done here in order to prevent possible over- and under-estimation problems. Turning back to the results, $1 \%$ increase in $Y$ seems to worsen $T B$ by $1.38 \%$ and $1.47 \%$ for $S C$ - and $A I C$-based models, respectively. The strongest factor affecting $T B$ in the study is $Y f$ that a $1 \%$ real growth of OECD in total, will ease Turkey's trade deficit by $4.38 \%$ and $5.73 \%$ according to $S C$ - and $A I C$-based model estimations, respectively. There is no significant effect of $O P$ on the $T B$.

When we added IIT to the model, the signs of all the variables remained the same, but the magnitudes of their coefficients changed. This is true for both models as seen in the second line of the Table 6. IIT is significantly positive on its own that $I I T$ also embodies impact on $T B$. Considerably decreases in the elasticities of REER and $Y$ after adding $I I T$, can be interpreted in a different way that the success of the depreciation partly depends on the availability of the similar products of the import basket in the domestic market. This is what IIT exactly measures. When $Y$ increases it is expected that the import also increases. Again, if Turkey produces goods that are similar to its import, i.e., high IIT, the import demand caused by the income increased can also be restricted.

In order to see the short-run coefficients, we estimated the model based on the equation-10 together with the error correction model structured in the equation-11 again with and without IIT for both SC and AIC models. Only significant coefficients are reported in the Table 7. Results comprise three important findings: First, since the real depreciation improves $T B$ in the short-run as well, there is no evidence found supporting the J-curve adjustment. This is true for the both models that M-L conditions is satisfied in both the long-run and the short-run. Secondly, there is no significant variable with a different sign in the short-run from those of the long-run. Finally, the error correction terms $\left(E C M_{t-1}\right)$ are significant and negative in the both models' estimations, indicating the convergence to long-run equilibrium of trade balance after a shock to its determinants. The speed of this adjustment is higher in the $S C$-based model with and without $I I T(0.89)$ than those of $A I C$-based ones without IIT (0.47) and with IIT (0.61) as expected since the AIC-based model let more lags in the model. When the models with IIT are considered, it is seen that a deviation from the long-term equilibrium is corrected by approximately $89 \%$ for the $S C$-based model and $61 \%$ for the AIC-based model over each period. In general, error correction terms point out a high-speed of convergence to equilibrium. 
Table 7. Error correction and short-run elasticities (dependent variable: $D\left(\ln T B_{t}\right)$

\begin{tabular}{|c|c|c|c|}
\hline Variables & Coefficients & Variables & Coefficients \\
\hline \multicolumn{2}{|c|}{$S C-A R D L(1,0,0,0,0):$ Without $\operatorname{lnIIT}$} & \multicolumn{2}{|c|}{$S C$-ARDL $(1,0,0,0,0,0):$ With lnIIT } \\
\hline$D(\ln R E E R)_{t}$ & $0.664[3.835]$ & $D(\ln R E E R)_{t}$ & $0.4270[2.590]$ \\
\hline$D(\ln Y)_{t}$ & $-1.217[-5.174]$ & $D(\ln Y)_{t}$ & $-0.890[-2.492]$ \\
\hline$D(\ln Y f)_{t}$ & $3.870[4.456]$ & $D(\ln Y f)_{t}$ & $3.527[2.922]$ \\
\hline \multirow[t]{2}{*}{$E C M_{t-1}$} & $-0.885[-7.615]$ & $D(\ln I I T)_{t}$ & $0.427[2.591]$ \\
\hline & & $E C M_{t-1}$ & $-0.885[-7.673]$ \\
\hline \multicolumn{2}{|c|}{ AIC-ARDL:(4,2,5,4,1): Without lnIIT } & \multicolumn{2}{|c|}{ AIC-ARDL:(4,2,5,4,5,4): With lnIIT } \\
\hline$D(\ln R E E R)_{t}$ & $0.432[2.366]$ & $D(\ln R E E R)_{t}$ & $0.196[2.513]$ \\
\hline$D(\ln R E E R)_{t-1}$ & $0.374 \quad[2.196]$ & $D(\ln R E E R)_{t-1}$ & $0.303[2.485]$ \\
\hline$D(\ln Y)_{t}$ & $-2.405[-3.903]$ & $D(\ln Y)_{t}$ & $-1.721[-2.513]$ \\
\hline$D(\ln Y)_{t-3}$ & $-2.455[-3.401]$ & $D(\ln Y)_{t-3}$ & $-2.521[-3.489]$ \\
\hline$D(\ln Y)_{t-4}$ & $1.301[2.476]$ & $D(\ln Y)_{t-4}$ & $-1.080[-2.208]$ \\
\hline$D(\ln Y f)_{t}$ & $5.280 \quad[2.144]$ & $D(\ln Y f)_{t}$ & $5.958[2.979]$ \\
\hline$D(\ln Y f)_{t-2}$ & $9.3424[2.402]$ & $D(\ln Y f)_{t-1}$ & $5.197[2.405]$ \\
\hline$D(\ln Y f)_{t-3}$ & $6.022[2.548]$ & $D(\ln Y f)_{t-2}$ & $5.767[2.449]$ \\
\hline$D(\ln O P)_{t}$ & $-0.416 \quad[-2.326]$ & $D(\ln Y f)_{t-3}$ & $3.043[2.363]$ \\
\hline$D(\ln T B)_{t-1}$ & $-0.539[-3.007]$ & $D(\ln O P)_{t}$ & $-0.474[-2.515]$ \\
\hline$D(\ln T B)_{t-2}$ & $0.629[4.166]$ & $D(\ln O P)_{t-4}$ & $-0.458[-2.119]$ \\
\hline$D(\ln T B)_{t-3}$ & $-0.719[-6.960]$ & $D(\ln T B)_{t-1}$ & $-0.040[-2.567]$ \\
\hline \multirow[t]{4}{*}{$E C M_{t-1}$} & $-0.472[-2.343]$ & $D(\ln T B)_{t-3}$ & 0.601 [4.173] \\
\hline & & $D(\ln I I T)_{t}$ & $0.586[2.208]$ \\
\hline & & $D(\ln I I T)_{t-1}$ & $0.457[3.001]$ \\
\hline & & $E C M_{t-1}$ & $-0.608[-3.072]$ \\
\hline
\end{tabular}

Notes. $t$-statistics are in the [brackets]. Only significant (\%5) coefficients are reported.

We conducted miscellaneous diagnostic tests to the residuals of the error correction model and found no significant evidence of serial correlation and heteroscedasticity. The models have also passed the stability and constancy thresholds on their coefficients. Overall, the diagnostic statistics indicate that there is no evidence of autocorrelation and heteroscedasticity for all models. In addition, CUSUM and CUSUM of square tests prove the stability of the coefficients on all model estimations.

Some studies in the related literature, (e.g. Narayan, 2006; Kyophilavong et al., 2013) recommend using impulse-response function especially while searching for J-curve evidence. Following Pesaran and Shin's (1998) method, we employed the generalized impulse response analysis using the VAR. The functions reveal that one standard deviation shock to the REER leads to a descending response of $T B$ over time and the impacts of shocks disappear after 6 quarters. This also confirms the absence of J-curve adjustment process. Moreover, we decomposed the variance again in the VAR. Results showed that $Y f$ explains $21 \%$ portion of $T B$ that is the highest share among variables. The shares of REER, Y, IIT and OP, for the 10 years period after the shock, 13\%, $11 \%, 10 \%$ and $6 \%$ respectively, those are consistent with the overall results of the study. Finally following Granger (1988)'s suggestion that if variables are cointegrated, there is causality running at least in one direction, we conducted Granger causality test within the VECM. The results indicated that there were significant causalities from $Y f$, REER, and $Y$ to the $T B$. In addition, there have been causalities found between the independent variables of this study (Note 5).

\section{Conclusion}

This study empirically tested how real effective exchange rate, domestic and foreign income, oil prices and intra-industry trade developments affect Turkey's trade balance in its manufactures trade with the OECD countries. The study differs from the related ones in mainly two ways. First, while the studies commonly use international crude oil prices, we computed final gasoline prices sold locally including all taxes in Turkey, to be able to capture the real cost of the oil to the production. Secondly, in the related literature, studies seem to be over-motivated in just searching Marshall-Lerner condition and J-curve. Our study also controlled the moderating effects of the availability of import substitutes proxied by intra-industry trade while investigating the relationships.

We analyzed quarterly aggregated time-series data of the period spanning from 1998.QI to 2015.QIII, following 
the procedures of the autoregressive distributed lag (ARDL) bounds testing approach to the cointegration and the error correction modeling. Because of the high sensitivity of coefficients to the lag lengths selected by criteria, we processed the analyses for both Schwarz and the Akaike information criterion-based models, in order to prevent possible over- and under-estimation problems. Results of both models were controlled adding intra-industry trade to each.

Consistent results of both model estimations reveal that real effective exchange rate, together with domestic and foreign incomes are still among the core determinants of Turkey's trade balance. The evidence that depreciations of the Turkish lira strongly improves trade balance in both the short-run and the long-run, indicates no evidence of J-curve adjustment process. The strongest factor affecting trade balance in our model is foreign income that $1 \%$ real growth of OECD in total, eases Turkey's trade deficit by $4.38 \%$ and $5.73 \%$ according to the Schwarz and the Akaike criterion based model estimations, respectively. The only factor influencing trade balance negatively in our model is domestic income, which means Turkey's growth tends to deteriorate trade balance by also increasing the import demand. There is no significant impact of domestic oil prices found on the trade balance, that is apparently consistent with previous studies' results. This insignificance possibly comes from the sectoral characteristics. Manufacturing sectors, especially medium and high tech ones are the knowledge-based production that is expected to have a lower dependency on the oil.

The Turkish lira has been experiencing a real depreciation recently. When considered the high exchange rate sensitivity of trade balance verified in the study, the question why Turkey's trade balance has not improved sufficiently, can be partly answered by the effect of the intra-industry trade. When we added intra-industry trade to the model, the signs of all the variables remained the same, but the magnitudes of their coefficients changed. Intra-industry trade is significantly positive on its own that means it also embodies impact on trade balance. Considerably decreases in the elasticities of the real effective exchange rate and domestic income after adding intra-industry trade, can be interpreted in a different way that the success of the depreciation partly depends on the availability of the locally produced goods similar to the import basket in the domestic market. Overall results confirm that exchange rate adjustments are not that effective alone and underline the importance of import-substitution capability along with the export-oriented production to ease the longstanding large trade deficits for Turkey. In this context, active policies encouraging the local producers to learn to produce goods similar to the imports can be a production-side solution. This is a long process requiring structural and integrated changes gradually, including subsidies, product diversification, technology transfer, adaptation, imitation, etc.

\section{References}

Ahmed, S., Appendino, M., \& Ruta, M. (2015). Depreciations without exports? Global value chains and the exchange rate elasticity of exports. The World Bank Group, Policy Research Working Papers, No.7390. http://dx.doi.org/10.1596/1813-9450-7390

Akbostanci, E. (2004). Dynamics of the trade balance: The Turkish j-curve. Emerging Markets Finance \& Trade, 40(5), 57-73. http://dx.doi.org/10.1080/1540496X.2004.1105258

Akkay, R. C. (2014). S-curve dynamics of trade between Turkey and her trading partners. International Journal of Economic and Administrative Studies, 8(15), 179-192. http://dx.doi.org/10.18092/ijeas.52534

Bahmani, M., Harvey, H., \& Hegerty, S. W. (2013). Empirical tests of the Marshall-Lerner condition: A literature review. Journal of Economic Studies, 40(3), 411-443. http://dx.doi.org/10.1108/01443581311283989

Bahmani-Oskooee, M., \& Alse, J. (1994). Short-run versus long-run effects of devaluation: Error-correction modeling and cointegration. Eastern Economic Journal, 20(4), 453-464.

Bahmani-Oskooee, M., \& Hegerty, S. W. (2010). The J-and S-curves: A survey of the recent literature. Journal of Economic Studies, 37(6), 580-596. http://dx.doi.org/10.1108/01443581011086639

Bahmani-Oskooee, M., \& Kutan, A. M. (2009). The J-curve in the emerging economies of Eastern Europe. Applied Economics, 41(20), 2523-2532. http://dx.doi.org/10.1080/00036840701235696

Bahmani-Oskooee, M., \& Ratha, A. (2004). The j curve: A literature review. Applied Economics, 36(13), 1377-1398. http://dx.doi.org/10.1080/0003684042000201794

Bailliu, J., \& Bouakez, H. (2004). Exchange rate pass-through in industrialized countries. Bank of Canada

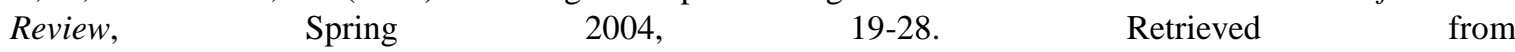
http://www.bankofcanada.ca/wp-content/uploads/2010/02/wp04-21.pdf

Bickerdike, C. F. (1920). The instability of foreign exchange. The Economic Journal, 30(117), 118-122. http://doi.org/10.2307/2223208 
Brada, J. C., Kutan, A. M., \& Zhou, S. (1997). The exchange rate and the balance of trade: The Turkish economy experience. The Journal of Development Studies, 33(5), 675-692. http://dx.doi.org/10.1080/00220389708422489

Brulhart, M. (2009). An account of global intra-industry trade, 1962-2006. The World Economy, 32(3), 401-459. http://dx.doi.org/10.1111/j.1467-9701.2009.01164.x

Celik, S., \& Kaya, H. (2010). Real exchange rates and bilateral trade dynamics of Turkey: Panel cointegration approach. Applied Economics Letters, 17(8), 791-795. http://dx.doi.org/10.1080/13504850802388993

Davis, D. R. (1995). Intra-industry trade: A Heckscher-Ohlin-Ricardo approach. Journal of International Economics, 39(3-4), 201-226. http://dx.doi.org/10.1016/0022-1996(95)01383-3

Devereux, M. B. (2000). How does a devaluation affect the current account? Journal of International Money and Finance, 19(6), 833-851 http://dx.doi.org/10.1016/S0261-5606(00)00035-8

Dickey, D. A., \& Fuller, W. A. (1981). Likelihood ratio statistics for autoregressive time series with a unit root. Econometrica, 49(4), 1057-1072. http://doi.org/10.2307/1912517

Edwards, L., \& Alves, P. (2006). South Africa's export performance: Determinants of export supply. South African Journal of Economics, 74(3), 473-500. http://doi.org/10.1111/j.1813-6982.2006.00087.x

Edwards, L., \& Garlick, R. (2008). Trade flows and the exchange rate in South Africa. MPRA Papers, 36666. Retrieved from https://mpra.ub.uni-muenchen.de/36666/

Eicher, T., Mutti, J. H., \& Turnovsky, M. H. (2009). International economics (7th ed.). London: Routledge.

Goldstein, M., \& Khan, M. S. (1985). Income and price effects of in foreign trade. Handbook of International Economics, 2(61), 1041-1105. http://dx.doi.org/10.1016/S1573-4404(85)02011-1

Granger, C. W. J. (1988). Some recent developments in a concept of causality. Journal of Econometrics, 39(1-2), 199-211. http://dx.doi.org/10.1016/0304-4076(88)90045-0

Grubel, H. G., \& Lloyd, P. J. (1975). Intra-industry trade: The theory and measurement of international trade in differentiated products. London: The Macmillan.

Gylfason, T., \& Risager, O. (1984). Does devaluation improve the current account? European Economic Review, 25(1), 37-64. http://dx.doi.org/10.1016/0014-2921(84)90070-9

Halicioglu, F. (2008). The bilateral j-curve: Turkey versus her 13 trading partners. Journal of Asian Economics, 19(3), 236-243. http://dx.doi.org/10.1016/j.asieco.2008.02.006

Hirschman, A. O. (1949). Devaluation and the trade balance: A note. The Review of Economics and Statistics, 31(1), 50-53. http://doi.org/10.2307/1927193

IMF. (2016). International Financial Statistics-IFS. Retrieved from http://data.imf.org/

Irhan, H. B., Alacahan, N. D., \& Korap, L. (2011). An empirical model for the Turkish trade balance: New evidence from ARDL bounds testing analyses. Ekonometri ve Istatistik, 14, 38-61. Retrieved from http://eidergisi.istanbul.edu.tr/sayi14/iueis14m3.pdf

Kale, P. (2001). Turkey's trade balance in the short-run and the long-run: An error correction modeling and cointegration. The International Trade Journal, 15(1), 27-56. http://doi.org/10.1080/088539001300005440

Kharroubi, E. (2011). The trade balance and the real exchange rate. BIS Quarterly Review, (September 2011), 33-42. Retrieved from http://www.bis.org/publ/qtrpdf/r_qt1109e.pdf

Kimbugwe, H. (2006). The bilateral j-curve hypothesis between Turkey and her 9 trading partners. Munich $\begin{array}{lllll}\text { Personal RePEc } & \text { Archive, } & \text { Retrieved } & \text { from }\end{array}$ https://mpra.ub.uni-muenchen.de/4254/1/MPRA_paper_4254.pdf

Korhonen, L., \& Ledyaeva, S. (2010). Trade linkages and macroeconomic effects of the price of oil. Energy Economics, 32(4), 848-856. http://doi.org/10.1016/j.eneco.2009.11.005

Krugman, P. R. (1990). Rethinking international trade. Cambridge, MA: The MIT Press.

Kwiatkowski, D., Phillips, P. C., Schmidt, P., \& Shin, Y. (1992). Testing the null hypothesis of stationarity against the alternative of a unit root: How sure are we that economic time series have a unit root? Journal of Econometrics, 54(1-3), 159-178. http://doi.org/10.1016/0304-4076(92)90104-Y

Kyophilavong, P., Shahbaz, M., \& Uddin, G. S. (2013). Does j-curve phenomenon exist in case of Laos? An $\begin{array}{lllll}\text { ARDL approach. Economic } & \text { 830 }\end{array}$ 
http://doi.org/10.1016/j.econmod.2013.08.014

Lerner, A. P. (1944). The economics of control: Principles of welfare economics. New York: The Macmillan

Magee, S. P. (1973). Currency contracts, pass-through, and devaluation. Brookings Papers on Economic Activity, (1), 303-325. http://doi.org/10.2307/2534091

Marshall, A. (1923). Money, credit and commerce. London: Macmillan.

Narayan, P. K. (2004). Reformulating critical values for the bounds f-statistics approach to cointegration: An application to the tourism demand model for Fiji. Retrieved from http://arrow.monash.edu.au/vital/access/\%20/services/Download/monash:7176/DOC

Narayan, P. K. (2006). Examining the relationship between trade balance and exchange rate: The case of China's trade with the USA. Applied Economics Letters, 13(8), 507-510.

Narayan, P. K., Sharma, S., Poon, W. C., \& Westerlund, J. (2014). Do oil prices predict economic growth? New global evidence. Energy Economics, 41, 137-146. http://doi.org/10.1016/j.eneco.2013.11.003

OECD. (2002). OECD economic outlook 2002. Paris: OECD. http://dx.doi.org/10.1787/eco_outlook-v2002-1-en

OECD. (2016). OECD economic outlook 2015. Retrieved from http://stats.oecd.org/

OPET. (2016). Daily oil price by cities. Retrieved from https://www.opet.com.tr/en/

Pancaro, C., \& Saborowski, C. (2015). Current account reversals in industrial countries: Does the exchange rate regime matter? International Journal of Finance \& Economics. http://doi.org/10.1002/ijfe.1535

Pesaran, M. H., Shin, Y., \& Smith, R. J. (2001). Bound testing approaches to the analysis of level relationships. Journal of Applied Econometrics, 16(3), 289-326. http://dx.doi.org/10.1002/jae.616

Pesaran, M. H., \& Shin, Y. (1998). Generalized impulse response analysis in linear multivariate models. Economics Letters, 58(1), 17-29. http://doi.org/10.1016/S0165-1765(97)00214-0

Pesaran, M. H., \& Shin, Y. (1999). An autoregressive distributed lag modelling approach to cointegration analysis. In S. Strom (Ed.), Econometrics and economic theory in the 20th century: The Ragnar Frisch centennial symposium. Cambridge: Cambridge University Press. http://dx.doi.org/10.1017/CCOL521633230.011

Rose, A. K., \& Yellen, J. L. (1989). Is there a j-curve? Journal of Monetary Economics, 24(1), 53-68. http://doi.org/10.1016/0304-3932(89)90016-0

Sinha, S. S. (2007). Comparative analysis of FDI in China and India: Can laggards learn from leaders? Boca Raton, FL: Dissertation.com Publishing.

TurkStat-Turkish Statistical Institute. (2016). Foreign trade statistics. Retrieved from http://www.turkstat.gov.tr/

UN. (2016). Product Classifications. Retrieved from http://unstats.un.org/unsd/cr/registry/regct.asp? $\mathrm{Lg}=1$

UN COMTRADE-United Nations Commodity Trade Statistics Database. (2016). Retrieved from http://comtrade.un.org

Yazici, M., \& Islam, M. Q. (2014). Exchange rate and bilateral trade balance of Turkey with EU (15) Countries. Journal of Business, Economics \& Finance, 3(3), 341-356.

Yazici, M. (2006). Is the j-curve effect observable in Turkish agricultural sector? Journal of Central European Agriculture, 7(2), 319-322. Retrieved from http://hrcak.srce.hr/ojs/index.php/jcea/article/view/377/322

\section{Notes}

Note 1. OECD member countries, in alphabetical order, are Australia, Austria, Belgium, Canada, Chile, Czech Republic, Denmark, Estonia, Finland, France, Germany, Greece, Hungary, Iceland, Ireland, Israel, Italy, Japan, Korea, Luxembourg, Mexico, Netherlands, New Zealand, Norway, Poland, Portugal, Slovak Republic, Slovenia, Spain, Sweden, Switzerland, (Turkey), the United Kingdom, the United States.

Note 2. Codes for manufacturing sectors are the sub-group of 15-37 under the tabulation category D for ISIC-Revision 3. For SITC-Revision 3, manufacturing codes are 5 to 8, except 667-68. See UN (2016) for detailed classification structures and further explanations.

Note 3. Brulhart (2009) provides comprehensive IIT measurements using the data of more than 39 million bilateral trade flows among more than 200 countries for the period 1962-2006 in yearly basis. Because we need 
the data until 2015 and as quarterly, we calculated a new data set for Turkey's manufacturing trade with the OECD countries. His calculations are in both SITC 3- and 5-digits level. However, we calculated in just SITC rev. 3, 3-digit level.

Note 4. There are also different approaches to measuring IIT. One takes trades in the similar products into account and the second one distinguishes the products by their quality and price characteristics. These two approaches are called horizontal IIT and vertical IIT, respectively. Moreover, there is also a marginal IIT, which gauges how the regular Grubel-Lloyd index varies when the marginal trade changes (see Brulhart, 2009, for further explanations). Our study does not classify IIT for its primary intended purposes.

Note 5. All the unreported results can be obtained from the author upon request.

\section{Copyrights}

Copyright for this article is retained by the author(s), with first publication rights granted to the journal.

This is an open-access article distributed under the terms and conditions of the Creative Commons Attribution license (http://creativecommons.org/licenses/by/3.0/). 